\title{
A Study on the Factors Affecting the Financial Performance of Select Commercial Banks of Ethiopia
}

\author{
Dr. Alaparthi Maruthi Varaprasad \\ Associate Professor of Accounting and Finance, Ambo University, Ambo, Ethiopia \\ Dr. Kota Madhusudhana Rao \\ Professor of Accounting and Finance, Ambo University, Ambo, Ethiopia
}

\begin{abstract}
This study examines the Analysis on financial performance determinants: A study on selected commercial Banks in Ethiopia. Among the total of 17 public and private sector banks by using Purposive sampling technique 9 banks have been selected for the study. Quantitative research approach was adopted by using secondary data by using panel data of banks over a period of ten years (2006-2015). The fixed effect model was chosen rather than random effect model based on the hausman specification test result. In order to realize the objectives of the study multiple regression models was employed. Banks specific factors considered CAMEL approach and the key macroeconomic factors such as gross domestic product, inflation rate and foreign exchange rate were also included to analyze the banks financial performance in terms of ROA and ROE, Accordingly, the result revealed that Capital adequacy has positive and significant impact on bank financial performance of return on asset, and Earning ability and liquidity management has negatively and significant impact on bank financial performance of return on equity, On the other hand, variables such as Gross Domestic Variable has positively impact on both return on asset (ROA) and return on equity (ROE).
\end{abstract}

Keywords: Financial performance, Banks.

DOI: $10.7176 /$ RJFA/10-9-02

Publication date:May $31^{\text {st }} 2019$

\section{INTRODUCTION}

Commercial banks play a vital role in the economic resource allocation of countries. They channel funds from depositors to investors continuously. They can do so, if they generate necessary income to cover their operational cost they incur in the due course. In other words for sustainable intermediation function, banks need to be profitable. Beyond the intermediation function, the financial performance of banks has critical implications for economic growth of countries. Good financial performance rewards the shareholders for their investment. This, in turn, encourages additional investment and brings about economic growth. On the other hand, poor banking performance can lead to banking failure and crisis which have negative repercussions on the economic growth. Financial performance is a subjective measure of how well a firm can use assets from its primary mode of business and generate revenues. It is also a general measure of a firm's overall financial health over a given period of time, and can be used to compare similar firms across the same industry or to compare industries or

\section{Statement of the problem}

Nowadays, examining the performance of commercial banks become very crucial for their profitable survival. The survival of commercial Banks in this dynamic economic environment is very dependent upon their good performance that based on scientific investigation. So, its wellbeing and successful operation captures the interest of different researchers and other professionals. Thus, a number of studies have examined the determinants of banks performance in many countries around the world.

\section{Objective of the study}

General objective

The main objective of this study to assess the factors affecting the financial performance of selected commercial Banks of Ethiopia.

\section{Specific objectives}

$>$ To identify the impact of Capital Adequacy on the financial performance of selected commercial banks of Ethiopia.

$>$ To see the effect of Asset Quality of selected commercial banks of Ethiopia

$>$ To examine the effect of Management Efficiency on the financial performance of selected commercial in Ethiopia.

$>$ To see the effect of Earning Ability of selected commercial banks of Ethiopia.

$>$ To examine the effect of Liquidity Management of selected commercial banks of Ethiopia. 
$>$ To study impact of Gross Domestic Product on the financial performance of selected commercial banks of Ethiopia.

$>$ To study impact of Foreign Exchange Rate on the financial performance of selected commercial banks of Ethiopia.

$>$ To study impact of InflationRate on the financial performance of selected commercial banks of Ethiopia.

\section{Hypotheses}

Hypothesis 1: There is positive and significant relationship between capital adequacy and financial performance of commercial banks.

Hypothesis 2: There is positive and significant relationship between asset quality and

financial performance of commercial banks.

Hypothesis 3: There is positive and significant relationship between management efficiency and banks financial performance.

Hypothesis 4: There is negative and significant relationship between earning ability and financial performance of commercial banks.

Hypothesis 5: There is positive and significant relationship between liquidity management and financial performance of commercial banks.

Hypothesis 6: There is positive and significant relationship between Gross domestic products and financial performance of commercial banks.

Hypothesis 7: There is negative and significant effect between inflation rate and financial performance of commercial banks.

Hypothesis 8: There is negative and significant effect between foreign exchange rate and financial performance of commercial banks

\section{Significance of the study}

This study is beneficial for different stakeholders such as

- management/Administration in identifying indicators of success and failure to take the necessary actions to improve the performance of the company and choose the right decisions,

- for Government in making better policies and necessary measures to avoid crises of the bankruptcy,

- for Investors to understand and to protect their investment by revising the portfolio of their investment and

- Customers are interested in knowing the ability of Commercial banks to deposit their make deposit based on the indicators of their success.

- Furthermore, this study has a paramount significance in providing a better enlighten for bank managers.

- The study will also concentrate on the management issues to identify the key variables that will boost profit.

\section{Scope of the Study}

- At present there exist 18 commercial banks excluding the construction and business bank which is recently merged with commercial bank of Ethiopia. Among the 18 commercial banks the study considered nine commercial banks

- The scope of the study is limited to 9 Commercial banks of Ethiopia including Awash International Banks, Dashen Bank S.C (DB), Bank of Abyssinia S.C (BOA), Wegagen Bank S.C (WB),United Bank S.C (UB), Nib International Bank S.C (NIB), Cooperative Bank of Oromia S.C (CBO) and Lion International Bank S.C (LIB) only.

Five internal variables like

1. Capital adequacy,

2. Asset quality,

3. Management,

4. Efficiency,

5. Liquidity management, (CAMEL) and

three external variables like

1. Gross Domestic Product,

2. Inflation Rate and

3. Foreign Exchange Rate are considered for the study.

The period of the study is limited to ten years (2006 -2015 GC). 


\section{Research Design}

Explanatory research design is adopted. Besides, this study used quantitative research approach to examine stated objectives.

\section{Data Analysis}

The panel data by combining time series of cross section observations,panel data give more revealing data, more inconsistency, less collinearity among variables, more degrees of freedom and more efficiency (Gujarati, 2004). By using STATA version13software, the collected panel data was analyzed using the descriptive statistics, correlationmatrix and multiple regressions. In case of the descriptive statistics, the mean, standarddeviation, maximum and minimum values were used to analyze the trends of the data whilethe correlation matrix was used to show the relationship exist between the variables used inthe study. Moreover, the diagnostic tests were undertaken in order to check the rationality of the model and fulfill the assumptions of the Classical Linear Regression Model.

\section{Dependent variables}

Return on Asset $(\mathrm{ROA})=\frac{\text { Net income before taxes }}{\text { Total asset }} \quad$ Return on Equity $\left.(\mathrm{ROE})\right)=\frac{\text { Net income after taxes }}{\text { Total Equity capital }}$

\section{Independent variables}

\section{A) Internal factors}

$$
\begin{aligned}
& \text { Capital adequacy }=\frac{\text { Total capital }}{\text { Total asset }} \text { Asset quality }=\frac{\text { Nonperfoming loan }}{\text { Total loan }} \\
& \text { Management efficiency }=\frac{\text { Total operating revenue }}{\text { Total profirt }} \text { Earning ability }=\frac{\text { Interest income }}{\text { Total income }}
\end{aligned}
$$

Liquidity management $=\frac{\text { Total loan }}{\text { Total deposit }}$

\section{B) External factors:}

Gross domestic product $=$ Yearly Gross Domestic product

Inflation rate $=$ Yearly average rate

Foreign exchange rate $=$ yearly exchange rate

\section{CONCEPTUAL FRAMEWORK:}

\section{(Dependent Variables)}

\begin{tabular}{|c|}
\hline Bank Specific Variables \\
$>$ Capital adequacy \\
$>$ Asset quality \\
$>$ Management \\
$\quad$ efficiency \\
$>$ Earning ability \\
$>$ Liquidity management
\end{tabular}

\begin{tabular}{|l} 
Macroeconomic Variables \\
$\quad>$ Gross Domestic Product \\
$>$ Inflation Rate \\
$>$ Foreign exchange rate
\end{tabular}

(Independent Variables)

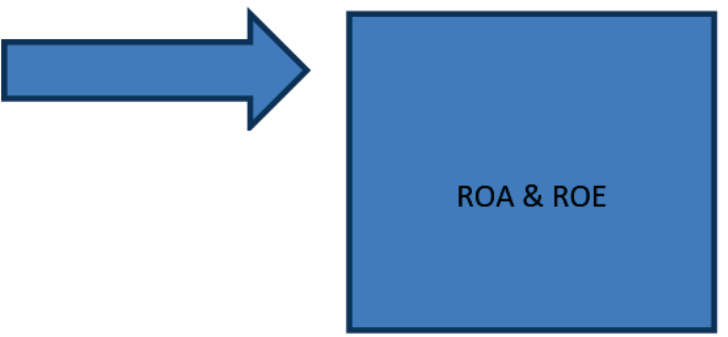

Source: Designed by researcher

Model Specification

\section{Model Specification}

The econometric model utilized for regression analysis is illustrated here below: 
ROAit $=\alpha 0+\alpha 1$ CAit $+\alpha 2$ AQit $+\alpha 3$ MEit $+\alpha 4$ EQit $+\alpha 5$ LMit $+\alpha 6$ GDPit $+\alpha$ 7INFLit $+\alpha 8$ FEX $+\varepsilon$ it

ROEit $=\alpha 0+\alpha 1$ CAit $+\alpha 2$ AQit $+\alpha 3$ MEit $+\alpha 4$ EQit $+\alpha 5$ LMit $+\alpha 6$ GDPit $+\alpha$ 7INFLit $+\alpha 8$ FEX $+\varepsilon$ it

ROAit $=$ Performance of Bank $i$ at time $t$ as expressed by ROA

ROEit $=$ Performance of Bank $i$ at time $t$ as expressed by ROE

$\alpha 0=$ Intercept

$\mathrm{CA}$ it $=$ Capital Adequacy of bank i at time $\mathrm{t}$

AQ it $=$ Asset Quality of bank i at time $t$

ME it = Management Efficiency of Bank i at time $t$

EQ it $=$ Earnings Quality of Bank i at time $t$

$\mathrm{LM}$ it $=$ Liquidity Ratio of Bank $\mathrm{i}$ at time $\mathrm{t}$

GDPit $=$ Gross domestic of $i$ at time $t$

INFLit=Inflation of bank $i$ at time $t$

FEXit $=$ Foreign exchange $i$ at time $t$

$\alpha 1-\alpha 5=$ Coefficients parameters

$\varepsilon i t=$ Error term where $\mathrm{i}$ is cross sectional and $\mathrm{t}$ time identifier.

\section{Model Assumptions}

Normality test: To check for normality, kurtosis and skewness of the distribution of the data will be examined descriptive statistics were used.

Multicollinearity: To check whether there is a strong correlation among the independent variables exists or not.There was different arguments towards the multicollinearity problem. (Gujarati D. N., 2004) Stated that multicollinearity problems exist when the correlation coefficient among variables greater than 0.75 . (Cooper \&Schendlar, 2003) Suggested that a correlationcoefficient valueis above 0.8 between explanatory variables should be corrected for. Lastly, (Hair JF, 2006) argued that also correlation coefficient below 0.9 may not cause serious multicollinearity problem. In contrary to this, (Kennedy, 2008) argued that as any correlation coefficient above 0.7 could cause a serious multi collinearity problem leading to inefficient estimation. A correlation matrix is used to ensure the correlation of explanatory variables.

Heteroscedasticity: If the errors do not have a constant variance, they are said to be heteroskedastic.According to (Brooks, 2008), heteroscedasticity means that error terms do not have a constant variance. There are several tests to detect the heteroscedasticity problem, which are Park Test, Glesjer Test, Breusch-Pagan-Goldfrey Test, Whites Test and Autoregressive Conditional heteroscedasticity test. In this case, this study chooses to use Autoregressive Conditional heteroscedasticity test to detect heteroscedasticity.

DATA ANALYSIS AND PRESENTATION

The data are analyzed by using STATA software version13.

ROA model normality test

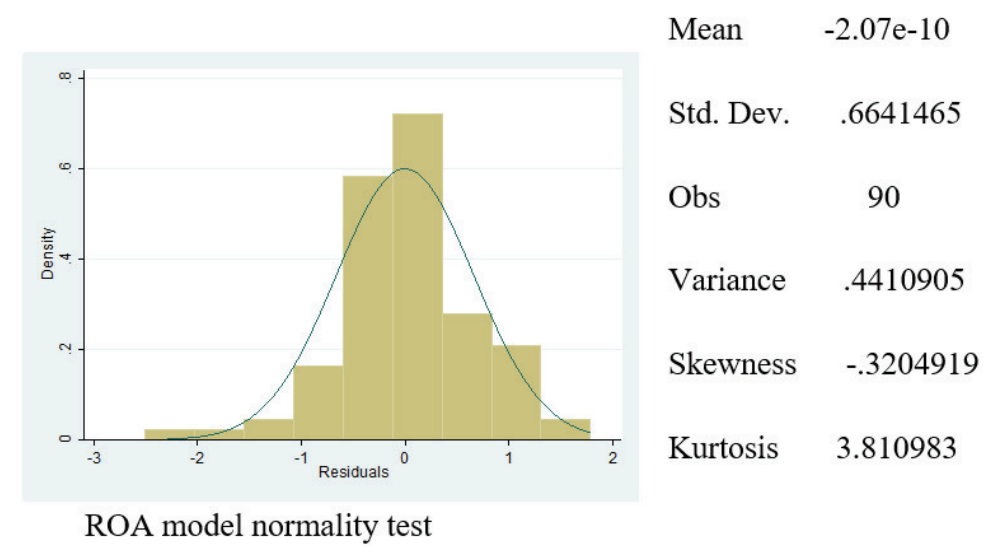

Source: from regression output 


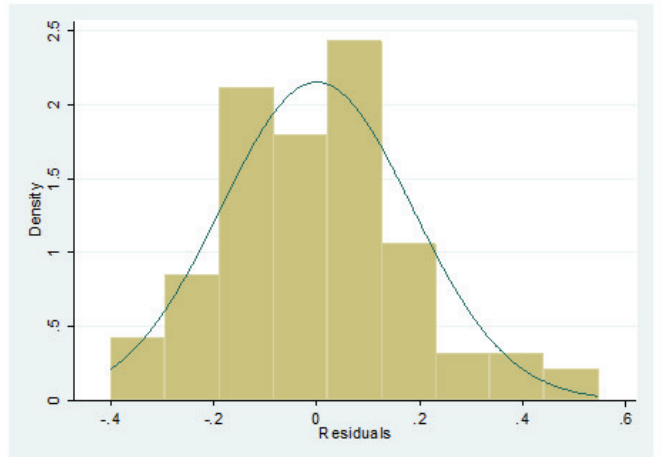

\section{Source: from regression output}

\section{ROE model normality test}

$\begin{array}{lr}\text { Mean } & -6.38 \mathrm{e}-10 \\ \text { Std. Dev. } & .1852466 \\ \text { Variance } & .0343163 \\ \text { Skewness } & .4609682 \\ \text { Kurtosis } & 3.34\end{array}$

\section{CONCLUSIONS}

Based on table 12,in relation to financial performance indicators measured by ROA,Management efficiency,capital adequacy,Inflation rate and gross domestic product are positively impact on banks financial performance measured by return on asset(ROA) but, asset quality,earning ability, liquidity management and Foreign exchange rate are negativelyimpact on the banks financial performance measured by return on asset (ROA)of Ethiopian commercial banks.

Capital adequacyand Asset qualityhave a p-value of 0.004 and 0.002 respectivelyand are significant at $5 \%$ level but the Earning ability and Liquidity managementhave bothp-valuesare 0.000 andstaticallysignificant at $1 \%$ level on banks financial performancemeasured by return on asset.

TheEarning ability, Liquidity management,and foreign exchange rate have significant impact on financial performance measured by return on equity (ROE).where as capital adequacy, assetquality, gross domestic product and Management efficiencyhave statically insignificant impact on banks financial performance measured by return on equity (ROE), Earning ability and Liquidity management areboth have a p-value of 0.000 each andarestaticallysignificant at $1 \%$ level respectively,and foreign exchange rate have the $p$-value of 0.043 and is significantat $5 \%$ level of significant.

Management efficiency, earning ability, Liquidity management,gross domestic product and foreign exchange rate arepositively impact onbanks financial performance measured by return on equity but Capital adequacy, assetquality and inflation rate,are negatively impact onbanks financial performance measured by return on equity.

With regard to macroeconomic factors, gross domestic product and inflation rate are positively insignificant influence tobanks financial performance measured by return on asset but foreign exchange rate have negativelyand insignificant impact on to banks financial performance measured by return on asset,but gross domestic product positively insignificant impactand foreign exchange rate have positively and significant influence on ROE, where asinflation ratenegatively in significantinfluence on ROE.

\section{Recommendation}

Earning ability and Liquidity management have statically significant at $1 \%$ level,Capital adequacy, Asset quality havestatically significant at 5\% impact on bank financial performance measured by return on asset and earning ability and liquidity management have stastically significant atstastically $1 \%$ level impact on bank financial performance measured by return on equity.

- Furthermore, from the macroeconomic factors foreign exchange rate have statistically significant impact on bank financial performance measured by return on equity at $5 \%$ level. Thus, the Ethiopian commercial banks cannot ignore the macroeconomic factors while formulating policies to improve the performance of the bank.

- Moreover, by carefully predicting the impact of macroeconomic factors commercial banks in Ethiopia can improve their performance.

- Since the management of the bank has control over the bank internal factors, it is possible to improve the performance of the bank by giving more attention on the identified bank specific factors such as, Capital adequacy, Asset quality, management efficiency, Earning ability and Liquidity management.

- Finally, we conclude that in order to investigate the determinants of financial performance of commercial banks in Ethiopiathe variables included in the study were not enough. Future researchers may include the rest unseen bank specific and macroeconomic variables to conduct study on determinants of financial performance of commercial banks in Ethiopia. 


\section{References}

Zerayehu et al., (2013) a sound financial system is indispensable for a healthy and vibrant economy.

$\mathrm{Geda}(2006)$ these banks were criticized for being wholly foreign owned.

(Gedey 1990, pp. 83, cited in Geda 2006).During the five-years of Italian occupation i.e during the period.

Goddard, J., Molyneux, P. and Wilson,S. J., 2004), Return on Assets (ROA) used by (Flamini, McDonald, \& Schumacher, 2009), the Return on Equity (ROE) and Return on Assets (ROA) utilized by (Athanasoglou, Delis, \&Staikouras, 2006).

Khrawish, 2011) that ROE is the ratio of Net Income after Taxes divided by Total Equity Capital.

DemirgucKuntetal.,(1998), Bikkeret al (2002), and Athanasoglouet al., (2008),

(Badola\&Verma , 2006) Made an attempt to identify the key determinants of profitability of Kosmidou, Tanna, \&Pasiouras, 2006, Investigates the impact of bank-

Kumbirai\& Webb, 2010 ,Made study on the performance of South Africa ${ }^{\text {ee }}$ commercial banking sector for the period 2005-2009.

Gul, Faiza, \& Khalid, 2011, examined the relationship between bank specific and macro-economic characteristics of bank profitability by using data of top fifteen Pakistani commercial banks over the period 2005-2009.

Alkhatib, 2012, Empirically examine the financial performance of five Palestinian commercial banks listed on Palestine securities exchange (PEX).to assess the financial performance of Palestinian commercial banks.

Lamarana, 2012,Examines the performance of the Malaysians local banks and foreign banks and compares their profitability in the financial sector. 